\title{
Effect of Plant Density on Yield and Other Quantitative Characters of the Maricongo Plantain (Musa acuminata X M. balbisiana, AAB) ${ }^{1}$
}

\author{
Héber Irizarry, José J. Green and Iván Hernaindez ${ }^{2}$
}

\section{ABSTRACT}

The effect of plant spacing and density upon various quantitative characters of the Maricongo plantain cultivar was evaluated. The planting patterns and densities per acre were: 10 by 5 feet, 871 plants; 10 by 4 feet, 1,089 plants; 6 by 6 feet, 1,210 plants; 6 by 5 feet, 1,452 plants and 5 by 5 feet, 1,742 plants.

Plants spaced 10 by 4 feet developed thicker trunks. The 5 by 5 feet spacing caused an apparent significant reduction in the weight and number of marketable fruits per bunch and also in the number of fruits of the second hand. Yield estimates per acre (as estimated from the lineal spacings between and within rows due to the slope of the terrain) revealed, however, that the closer spacing was capable of producing 21.1 tons of plantains equivalent to 5.1 tons of dry pulp or 69,897 marketable fruits. Plant spacing and density did not affect other characters studied pertaining to the plant, bunch and individual fruit.

The bunch shooting pattern demonstrated that flower induction and harvest were somewhat delayed under close spacing and high plant density.

\section{INTRODUCTION}

Plantains (Musa acuminata $\times M$. balbisiana, AAB) presently rank third among crops of economic importance in Puerto Rico. Farm value during the fiscal year 1972-73, was $\$ 16.8$ million, thus contributing to the gross agricultural income of the island by 5.2 percent, an increase of $\$ 2.5$ million over the previous year. Certain agronomic problems must be solved, however, for this crop to continue increasing in economic importance. One of the problems that needs immediate solution is the lack of disease-free propagating material capable of producing bunches with a large number of uniform fruits. Other needs are for new information updating recommendations for spacing and for planting dates. Solution to these problems undoubtedly would result in higher yields, better fruit quality, and a steady supply of

1 Manuscript submitted to the Editorial Board November 7, 1974.

Associate Plant Breeder, Research Assistant and Assistant Chemical Engineer, respectively, Agricultural Experiment Station, Mayagüez Campus, University of Puerto Rico, Río Piedras, Puerto Rico. 
plantains throughout the year. Lower prices presumably should result at the consumer level and the market stabilization.

Local plantain farming is limited mainly to two cultivars; Maricongo, which is planted on about 80 percent of the total cultivated area, and Common Dwarf the remainder (3). A wide range of clonal variations occur within these two cultivars, however, with descriptive names assigned in the different localities to the various clones thus making varietal characterization exceedingly difficult. This perhaps is the case of the so-called "Guayamero" plantain which Sánchez-Nieva et al. (6) compared with the Maricongo cultivar. Both plantains are quite similar, except for the number of fruits per bunch and individual fruit weight.

Plantains show variable responses to plant spacing and densities. In rows 10 feet apart, Vicente-Chandler and Figarella (7) did not detect any effect on yield by increasing the number of plants per acre from 800 to 1,300 . Planted at intervals of 6 by 5 feet, however, Caro-Costas (2) obtained a sharp increase in number of fruits per acre by increasing plant densities from 1,090 to 1,450 plants. Both experiments were established in the municipality of Orocovis using unselected seed of the Maricongo cultivar.

This report summarizes the results of an evaluation of the effects of five plant densities on individual quantitative characters of the plant, bunch and fruit of the Maricongo cultivar.

\section{MATERIALS AND METHODS}

An experiment was initiated on August 26, 1971 at the Corozal Substation in a Corozal clay (Ultisol) with a $\mathrm{pH}$ of 4.6 and about 40 percent slope. Five plant densities were tested in an incomplete block design. The experimental plots consisted of 12 to 24 plants, depending on the planting distance, and each treatment was replicated 4 times.

The plant density treatments per acre were: 10 by 5 feet, 871 plants; 10 by 4 feet, 1,089 plants; 6 by 6 feet, 1,210 plants; 6 by 5 feet, 1,452 plants and 5 by 5 feet, 1,742 plants, respectively. In practice, these spacings represent lineal distances between and within rows due to the slope of the terrain. The rows were oriented in an east-west direction.

The seed was carefully selected on a private local farm. Plants were labeled during the harvesting process and only Maricongo plants bearing 50 or more fruits per bunch and apparently virus-free were used for propagation. Seed weight was used as a criterion for uniformity. The average weight was 1.6 pounds per peeled seed. The seed subsequently was dipped for 5 minutes in a nematicide-insecticide solution containing $11 \mathrm{ml}$ of Nemagon $(\mathrm{DBCP})^{8} 70-75 \mathrm{E}$. C. and $25 \mathrm{ml}$ Aldrin per gallon of water.

\footnotetext{
3 Trade names are used in this publication solely for the purpose of providing specific information. Mention of a trade name does not constitute a guarantee or war-
} 
The soil prior to planting was plowed with a walking hillside plow and limestone was applied at the rate of 4 tons per acre.

The plots were fertilized approximately 1,5 and 9 months after planting. A fertilizer containing 200 pounds of $N, 200$ pounds of $\mathrm{P}_{2} \mathrm{O}_{5}, 480$ pounds of $\mathrm{K}_{2} \mathrm{O}$ and 166 pounds of $\mathrm{MgO}$ per ton was applied at the rate of 4.5 pounds per plant, divided in 3 equal applications (1).

Weeds were controlled with pre- and post-emergence applications of an herbicide mixture containing 2 pints of Gramoxone (Paraquat), 5 pounds of Dalapon (Dowpon) and 1 pint of Ortho X-77 Spreader sticker in 50 gallons of water per acre. Occasionally, additional applications of an herbicide were made containing 5 pounds of Dalapon, plus 2 pounds of Karmex (Diuron) in 50 gallons of water.

Insects and nematodes were controlled with applications of Dasanit (Terracur P) at the rate of 2 ounces per plant every 6 months. A Sigatoka leaf spot control program was initiated about 6 months after planting. The plants were sprayed every 21 days with a fungicide mixture containing 0.5 pound of Benlate (Benomyl), 2 pints of Esso orchard oil, $15 \mathrm{ml}$ of Triton $\mathrm{X}-45$ plus enough water to complete 2 gallons.

Rainfall distribution, and the average maximum and minimum temperatures prevailing at the Corozal Substation is presented from planting until the end of the main harvest (fig. 1).

Data of the following plant characters at the time of bunch shooting were recorded: number of functional leaves, plant height and trunk diameter. These measurements were taken from the base of the plant to the point of bunch initiation, and 1 meter above the base of the trunk, respectively. All bunches were harvested approximately $\mathbf{1 1 0}$ days from the bunch shooting date. During harvest, data of the following plant and bunch characters were recorded: number of functional leaves and suckers per plant, weight and number of marketable fruits per bunch, number of fruits in the first and second hands, and total hands per bunch. The last fruit bearing hand of the bunch usually is of no commercial value, thus not counted. Fruits of the third hand of the bunch subsequently were processed. Data of mean fruit weight, external fruit length and narrower and wider diameters, pulp:peel ratio, pulp percentage, and texture were recorded. These fruit indexes were obtained using the procedures described by Sánchez-Nieva et al. $(5,6)$.

\section{RESULTS AND DISCUSSION}

Only trunk diameter, among the five characters observed in the Maricongo plant, apparently was affected by plant density. Plants spaced 10 by

ranty of equipment or materials by the Agricultural Experiment Station of the University or Puerto Rico or an endorsement over other equipment or materials not mentioned. 

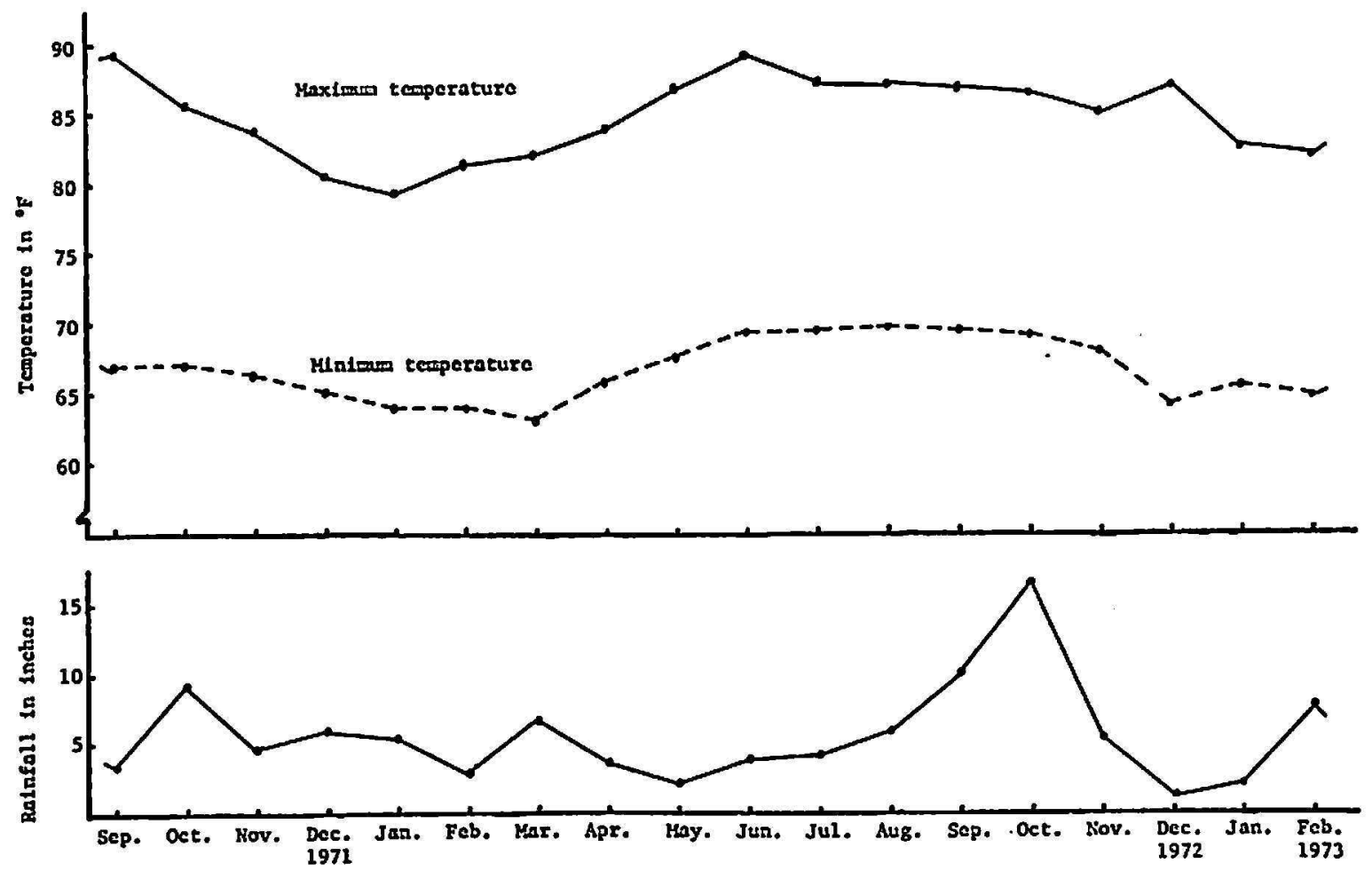

Fia. 1.-Monthly rainfall and average maximum and minimum air temperatures recorded from September 1, 1971 to February 28, 1973.

4 feet developed thicker trunks than those of the other treatments (table 1). The observed differences were significant at the 5-percent level of probability. The recorded mean values for number of functional leaves, plant height and trunk diameter at bunch-shooting, and number of functional leaves and plant suckers at harvest were: 12.7 leaves, 11.2 feet, 6.4 inches, 8.7 leaves and 8.3 suckers, respectively.

Some growers have claimed closer spacing in plantains enhanced sprouting of suckers. This assumption was not substantiated as there were no signifi-

TABLE 1.-Trunk diameter, bunch weight, and number of marketable fruits per bunch and second hand of the Maricongo cultivar as affected by plant spacing and density at the Corozal Substation

\begin{tabular}{|c|c|c|c|c|c|}
\hline \multirow{2}{*}{$\begin{array}{l}\text { Plant density } \\
\text { per acre }\end{array}$} & \multirow{2}{*}{ Plant spacing } & \multirow{2}{*}{$\begin{array}{c}\text { Trunk mean } \\
\text { diameter }\end{array}$} & \multirow{2}{*}{$\begin{array}{l}\text { Bunch mean } \\
\text { weight }\end{array}$} & \multicolumn{2}{|c|}{ Marketable fruits per } \\
\hline & & & & Bunch & Second hand \\
\hline Number & Reet & Inches & Pounds & Number & Number \\
\hline 871 & 10 by 5 & $6.3^{b}$ & $27.9^{\mathrm{ab}}$ & $45.6^{\mathrm{ab}}$ & $8.5^{a}$ \\
\hline 1,089 & 10 by 4 & $6.8^{a}$ & $32.0^{\mathrm{a}}$ & $47.8^{\mathrm{a}}$ & $8.7^{\mathrm{a}}$ \\
\hline 1,210 & 6 by 6 & $6.4^{b}$ & $29.0^{\mathrm{ab}}$ & $45.5^{a b}$ & $8.3^{\mathrm{ab}}$ \\
\hline 1,452 & 6 by 5 & $6.4^{b}$ & $28.2^{\mathrm{ab}}$ & $42.5^{\mathrm{ab}}$ & $8.3^{a b}$ \\
\hline 1,742 & 5 by 5 & $6.3^{\mathrm{b}}$ & $24.2^{\mathrm{b}}$ & $40.1^{b}$ & $7.7^{\mathrm{b}}$ \\
\hline
\end{tabular}

1 Values followed by the same letter are not significantly different at the 5-percent level of probability. 
cant differences between the number of suckers sprouting at different spacings. Field observations revealed that sucker growth is retarded in increased plant density due perhaps to excessive shading, and harvest of the ratoon crop delayed. Planting more closely, however, might contribute to more uniformity in weight and size of the seed, thus contributing to a more uniform harvesting pattern of the ratoon crop as well as in new plantings established from this seed.

Plant spacing and density apparently exerted a significant effect on weight and number of marketable fruits per bunch and in the number of fruits of the second hand (table 1). Aside from the spacing treatment of 10 by 5 feet there was an inverse relationship between plant density and both weight and number of marketable fruits per bunch. An increase in density resulted in a progressive decrease in weight and number of marketable fruits. Detected differences were significant, however, only when the bunches harvested in the spacing treatment of 10 by 4 feet outyielded those obtained in the closer spacing of 5 by 5 feet by 8 pounds or 8 fruits, respectively. These differences were significant at the 5-percent level of probability.

With respect to number of fruits in the second hand, the bunches harvested in the wider spacing treatments of 10 by 5 and 10 by 4 feet contained significantly more fruits in this hand than the similar hand of those harvested in the closer spacing of 5 by 5 feet. As in trunk diameter, bunch weight and number of marketable fruits per bunch, an increase in density beyond 1,089 plants resulted in a decrease in the number of fruits of the second hand.

As total hands and number of fruits in the first hand of the bunch were not affected by by plant spacing, the reduced weight and number of marketable fruits detected in bunches harvested in the closer planting treatment may be the result of a progressive reduction in number of fruits beyond the first hand. Recorded mean values for bunch weight, number of marketable fruits, total hands and number of fruits in the first and second hands were as follows: 28.3 pounds, 44.3 fruits, 7.3 hands, 9.3 and 8.3 fruits, respectively. In spite of the apparent detrimental effect of closer spacing upon number of marketable fruits per bunch, the mean production of 44 fruits per bunch clearly evidences the importance of using virus-free high yielding maternal plants as the seed source for plantain production. According to EspinetColón et al. (3), the average yield of the Maricongo cultivar in commercial plantings is only 28 marketable fruits per bunch.

The influence of plant spacing or density on seven fruit characters of the third hand of the bunch showed no significant effect upon these characters. Mean values obtained were as follows: fruit weight, 283.1 grams; fruit length, wider and narrower diameters, 7.8, 1.9 and 1.7 inches, respectively; pulp:peel ratio, 1.6; pulp content, 61.8 percent and texture, 694.0 pounds 
per square inch. Except for the mean fruit weight, external length and texture the other fruit values are compatible with previous findings reported by Sánchez-Nieva et al. $(5,6)$. This might suggest that plant density variation within the limits tested in the experiment and in soils similar in slope to that of the experimental field, is not detrimental to individual fruit quality.

Yield estimates based on total weight and number of marketable fruits per acre are presented in table 2. As shown, a reduction in plant spacing, that is, an increase in plant density, resulted in an increase of both weight and number of marketable fruits per acre. The closer planting was capable of yielding 42,208 pounds (21.1 tons) of plantains equivalent to 5.1 tons of dry pulp or 69,897 marketable fruits per acre, whereas the wider planting of 10 by 5 feet had a capacity of producing only 24,697 pounds ( 12.3 tons) of plantains equivalent to 2.9 tons of dry pulp or 39,977 marketable fruits.

TABLE 2.-Estimated weight and mean number of marketable fruits per acre of the Maricongo cultivar as affected by plant spacing and density at the Corozal Substation

\begin{tabular}{cccc}
\hline Plant density per acre & Plant spacing & Weight estimate per acre & Fruit estimate per acre \\
\hline Number & Feel & Pounds & Number \\
1,742 & 5 by 5 & $42,207.9^{\mathrm{a}}$ & $69,896.6^{\mathrm{a}}$ \\
1,452 & 6 by 5 & $41,050.8^{\mathrm{a}}$ & $61,827.7^{\mathrm{b}}$ \\
1,210 & 6 by 6 & $34,985.3^{\mathrm{a}}$ & $55,019.5^{\text {od }}$ \\
1,089 & 10 by 4 & $34,843.3^{\mathrm{a}}$ & $52,068.5^{\mathrm{d}}$ \\
871 & 10 by 5 & $24,696.7^{\mathrm{b}}$ & $39,976.8^{\mathrm{o}}$ \\
\hline
\end{tabular}

1 Values followed by the same letter are not significantly different at the 1-percent level of probability.

Treatment differences were highly significant at the 1-percent level of probability. The remaining planting treatments significantly outweighed the wider planting of 10 by 5 feet but differences among these treatments were not significant.

With regard to the number of marketable fruits, except for the comparison between the 6 by 6 and 10 by 4 feet spacings, the other possible comparisons among treatments were highly significant. Reduction in plant spacing was accompanied with a consistent increase in number of marketable fruits per acre. This might suggest maximum yield response of plantain to closer spacing is beyond that of 5 by 5 feet under similar experimental conditions. The potential 39,977 marketable fruits that can be harvested in an acre planted at the wider distance of 10 by 5 feet and using selected seed, clearly evidenced the economic importance of using superior seed for plantain production in Puerto Rico. It has been reported by Espinet-Colón et al. (3) that under conventional spacing methods (about 700-800 plants per acre) 
plantain yield in Puerto Rico is estimated at only 20,890 marketable fruits per acre.

An estimate of the income that might be expected from an acre of plantain spaced 5 by 5 feet, and using seed originating from maternal plants bearing a large number of fruits per bunch is presented in table 3 . The 59,200 marketable fruits expected to be harvested are only 2 percent more than the actual yield per acre obtained in a planting of 6 by 5 feet under intensive management (4).

Other crop responses observed throughout the experiment were the bunch-shooting and the bunch harvesting patterns. The bunch-shooting peaks and their corresponding induction percentages observed in each planting treatment are presented in figure 2. The bunch-shooting peaks

TABLE 3.-Estimated income from the first harvest of a plantain field, spaced 5 by 5 feet with a density of 1,742 plants per acre ${ }^{1}$

\begin{tabular}{lclcc}
\multicolumn{1}{c}{ Income and cost } & Yield & \multicolumn{1}{c}{ Unit } & Price/unit & \multicolumn{1}{c}{ Value } \\
\hline Expected income from & $59,200^{2}$ & Marketable fruits & $\$ 0.06$ & $\$ 3,552.00$ \\
Expected income from & 4,400 & Seeds & 0.10 & 444.00 \\
& & & & $3,996.00$ \\
Gross income & & & $1,500.00$ \\
Less cost of production & & & $\$ 2,496.00$ \\
Net income & & &
\end{tabular}

1 In practice the efficiency of such a planting method may be only 85 percent.

2 It is assumed that 1,480 plants will produce 59,200 marketable fruits and an average of three propagating seeds per plant.

were observed to occur from July through November, 1972. About 84 percent of the experimental plants bore bunches during these months. In the wider plantings of 10 by 5 and 10 by 4 feet the bunch-shooting peaks lasted for the four month period July through October 1972, whereas in the closer spacings of 6 by 6,6 by 5 and 5 by 5 feet the shooting peaks were extended to the five month period July through November 1972. Bunchshooting percentages obtained with increasing planting density throughout the range of the visible peaks were $84.7,76.6,84.0,86.7$ and 86.8 , respectively.

About 79 percent of the experiment was harvested during the five month period October 1972 through February 1973. The harvesting peaks and their corresponding harvesting percentages occurring in each plant spacing are presented in figure 3 . In the wider plantings of 10 by 5 and 10 by 4 feet the harvesting peaks occurred from October 1972 through January 1973, whereas in the closer plantings of 6 by 6,6 by 5 and 5 by 5 feet these peaks 


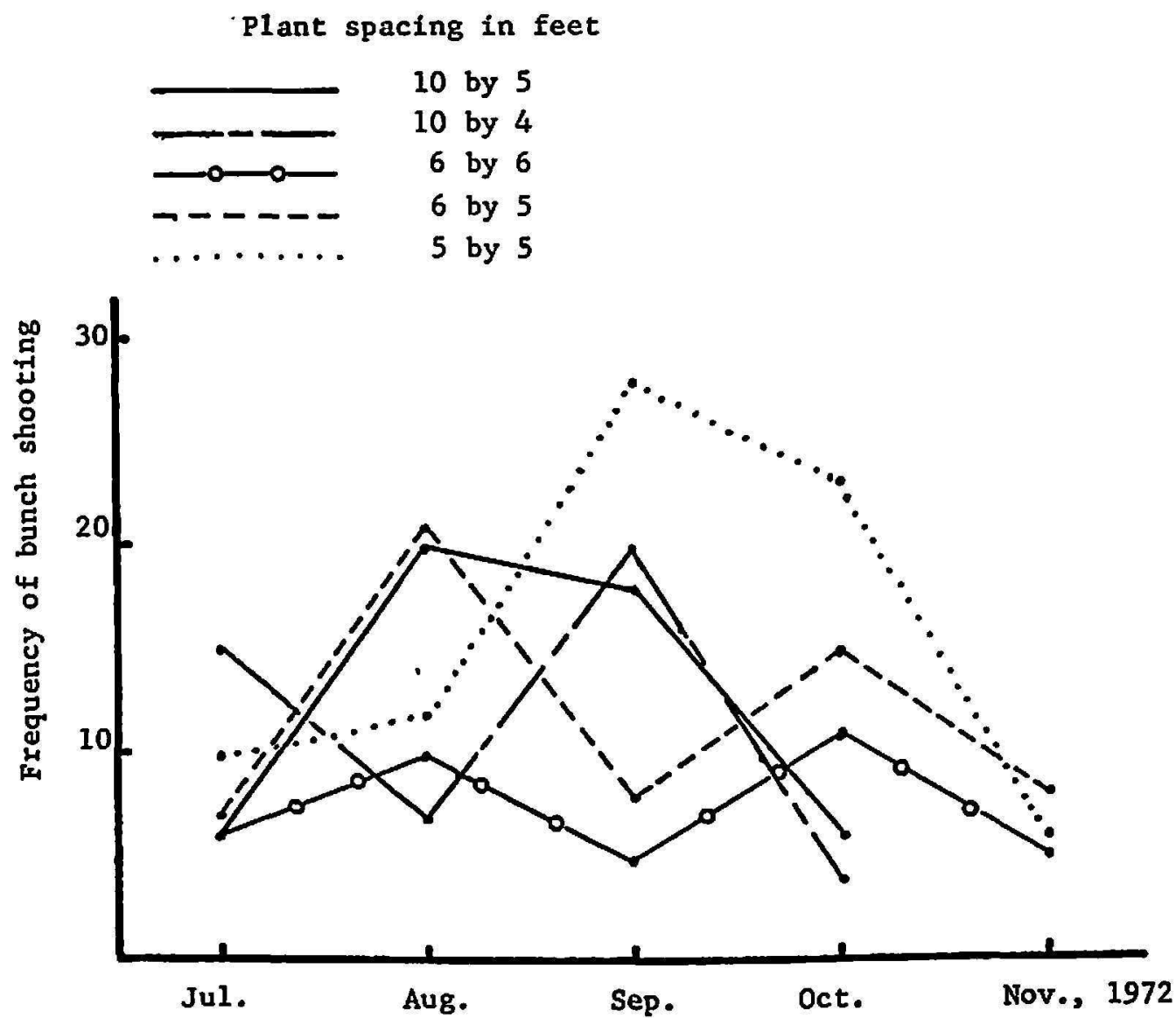

FIG. 2.-Number of plants shooting at each of the indicated dates.

Plant spacing in feet
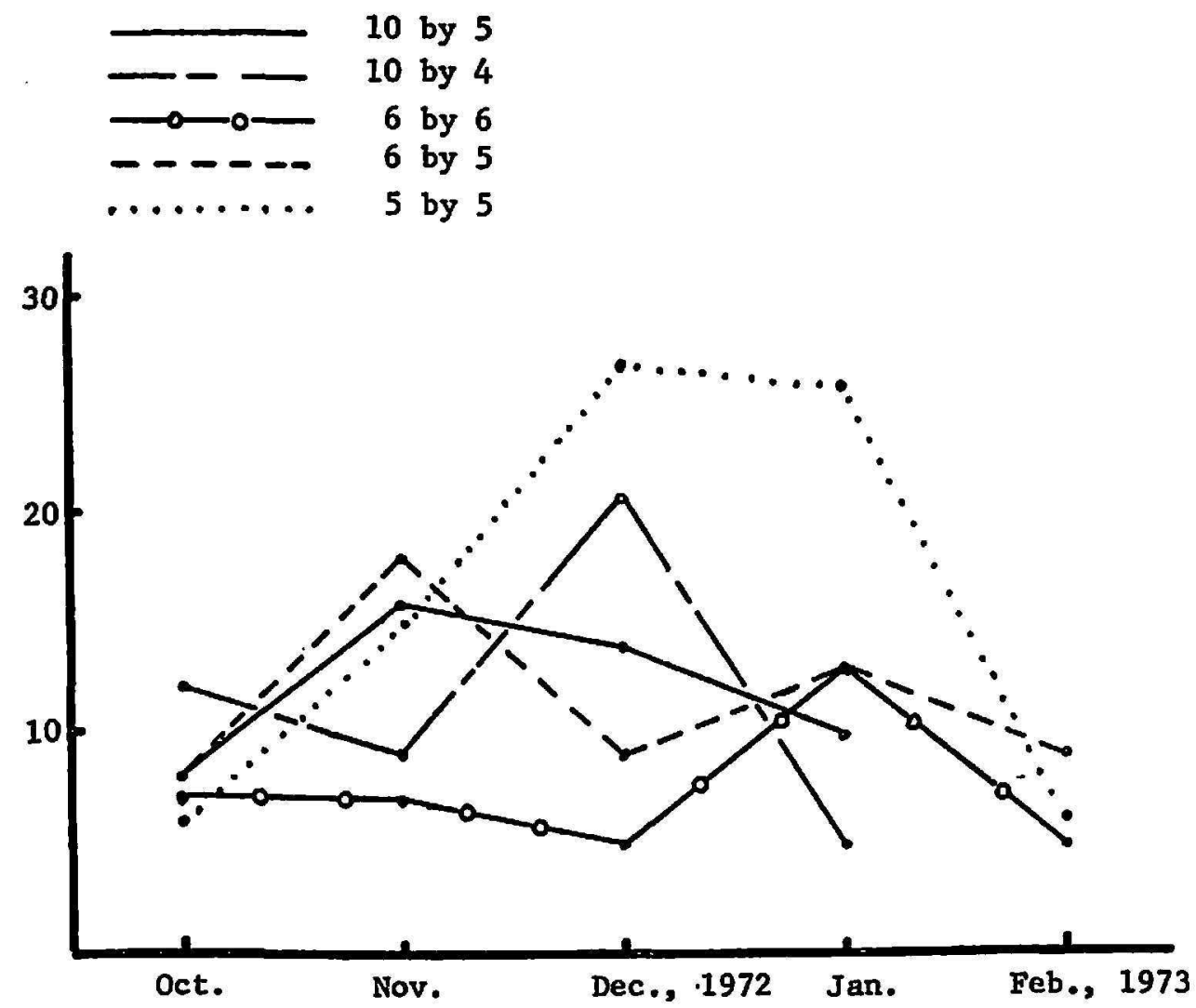

Fia. 3.-Number of bunches harvested at each of the indicated dates. 
were extended through February 1973. The harvesting percentages recorded with increasing planting density throughout the range of the visible peaks were 80.0, 77.0, 75.5, 79.1 and 82.4, respectively. Bunch shooting behavior and the harvesting patterns suggest that close plant spacing prolonged the main harvest.

As shown in the partial climatological data recorded in figure 1 , both maximum and minimum air temperatures were fairly stable from July through November 1972, whereas an increase in rainfall was registered from July through October 1972. This weather pattern coincided with the exhibition of the bunch-shooting peaks. Except for the month of December 1972, the rainfall distribution pattern from planting until the completion of the main harvest was normal or above normal. However, the 1.4 inches of rainfall recorded during December was 1.2 inches less than the normal rainfall for this month at the Corozal Substation. This drop in rainfall was accompanied with a rise in the maximum temperature. The main harvest of the experiment occurred during this month.

\section{RESUMEN}

En agosto de 1971 se inició un estudio en la Subestación de Corozal para evaluar el efecto de la distancia y la densidad de siembra sobre varios caracteres cuantitativos de la planta, el racimo y la fruta del plátano Maricongo (Musa acuminata $\times M$. balbisiana, AAB).

Los tratamientos y sus respectivas densidades estimadas por acre fueron los siguientes: 10 por 5 pies, 871 plantas; 10 por 4 pies, 1,089 plantas; 6 por 6 pies, 1,210 plantas; 6 por 5 pies, 1,452 plantas; y 5 por 5 pies 1,742 plantas.

Al tiempo de la inducción del racimo y de la cosecha se recopilaron datos de los siguientes caracteres: número de hojas funcionales, diámetro y altura de las plantas, número de retoños (hijos), peso y número de frutas vendibles por racimo, total de manos y número de frutas en las primera y segunda manos del racimo. Posteriormente, de las frutas de la tercera mano del racimo se tomaron datos de los siguientes caracteres: peso medio, diámetros angosto y ancho, largo externo, proporción entre pulpa y cáscara, porcentaje de pulpa y textura.

Todos los racimos de las plantas experimentales se cosecharon aproximadamente a los 110 días a partir de la fecha de la inducción.

Los resultados indican que de todos los caracteres observados solamente el grueso de los tallos, el peso y número de frutas vendibles por racimo y el número de frutas en la segunda mano del racimo parecen ser afectados por la distancia de siembra.

Los estimados de producción a base del peso total y el número de frutas vendibles por acre indican que la siembra a 5 por 5 pies podría producir aproximadamente 21.1 toneladas de plátano, equivalentes a 69,897 frutas, o 5.1 toneladas de pulpa seca.

\section{LITERATURE CITED}

1. Caro-Costas, R., Abruña-Rodríguez, F., and Vicente-Chandler, J., Response to fertilization of strip-cultivated plantains growing on a steep latosol in the humid mountain region of Puerto Rico, J. Agr. Univ. P.R., 48(4) : 312-317, 1964.

2. - Effect of plant population and distribution on yields of plantains, J. Agr. Univ. P.R., 52(3) : 256-259, 1968. 
3. Espinet-Colón, G. R., González-Villafañe, E., Muler-Manzanares, L. y Chavarría de Gracia, O., Análisis económico de la producción y mercadeo del plátano a nivel del productor, Puerto Rico, 1971-72, Publ. 82, Est. Exp. Agr. Univ. P.R., Sept. 1973.

4. Llorens, A., Personal Communication.

5. Sánchez-Nieva, F., Colom-Covas, G., Hernández, I., Guadalupe, R., Diaz, N., and Viñas, C. B., Preharvest changes in the physical and chemical properties of plantains, J. Agr. Univ. P.R., 52(3) : 241-255, 1968.

6. - - Hernández, I., Colom-Covas, G., Guadalupe, R., Diaz, N., and Viñas, C. B., A comparative study of some characteristics of two plantain cultivars which affect yield and product quality, J. Agr. Univ. P.R., 52(4) : 323-338, 1968.

7. Vicente-Chandler, J., and Figarella, J., Experiments on plantain production with conservation in the mountain region of Puerto Rico, J. Agr. Univ. P.R., 46(3): 226-236, 1962. 